\title{
Evaluation of Feeding Stimulant Mixed with Chemical and Bio Insecticides on Certain Lepidopterous Pests and their Natural Enemies in Cotton and Soybean Fields
}

\section{Mona B. R. El Mandarawy*, Moustafa A.Z. El Naggar and Saadia A. Abdel Samae}

\author{
Plant Protection Research Institute, A.R.C., Dokki, Giza, Egypt
}

*E-mail address: Mmandarawy@yahoo.com

\begin{abstract}
The Efficiency of feeding stimulants (Bioenhencer) was studied alone and in combinations with chemical insecticides or entomopathogens against the defoliating pests, Spodoptera littoralis (Boisd.) and Spodoptera exigua Hbn. (in fields of cotton and soybean) and the bollworms Pectinophora gossypiella Saunders and Earias insulana Boisd. (in cotton field), at Kafr El-Sheikh governorate during the season 2003. Its adversely influence on the natural enemies associated these pests in the two fields, were also undertaken. Laboratory results indicated that the feed stimulant was exhibited at a high degree of efficiency against the target lepidopterous larvae when combined with the chemical insecticide and the bioinsecticides. But no obvious effect was found when it was used alone. Field results indicated that, the addition of Bioenhencer (5\%) to the chemical and bio insecticides enhanced their activity, where the damaged rate significantly affected in these treated plots as compared to the untreated ones, on both cotton and soybean fields. Moreover, bioenhancer and the bioinsecticide had the least harmful effect on the entomophagous insect populations. @JASEM
\end{abstract}

Massive applications of insecticide result in adverse effects on beneficial organisms, leaves their residues in the food and result in environmental pollution. Accordingly, chemical control of pests has declined in many countries by using the regulatory mechanisms, environmental activism and using biological control items and increasing their efficiency. This has necessitated the use of target specific compounds with low persistence and an increase in emphasis on integrated pest management (Sharma et al. 2000). Therefore, the uses of behavioral chemicals, which include general categories of feeding stimulants and semiochemicals have broad potential applicability. Also, adding of feeding stimulants to chemical insecticides and entomopathogens may be benefits in increasing the effectiveness of the control and were allowed the application dosages of insecticides to be reduced (Chandler, 1993; Hough-Goldstein et al., 1991 and Potter \& Watson 1983).

In Egyptian cotton fields, the cotton leaf worm, Spodoptera littoralis (Boisd.) and the lesser cotton leafworm (Beet armyworm) Spodoptera exigua Hbn. are among the most serious defoliators threaten the crop. Also, the cotton boll worms, the pink bollworm, Pectinophora gossypiella Saunders and the spiny bollworm, Earias insulana Boisd. cause the greatest part of cotton yield losses (Amin et al., 2001). As well, foliage-eating insects are present in all soybean fields throughout the growing season. Younger plants, which have not begun to bloom or to fill pods, can tolerate greater foliage damage than the plants that are fruiting, (El-Kifl et al., 1974; Hamed, 1977 and Tantawy et al., 1989).

The present work was designed to evaluate the effect of a feeding stimulant (Bioenhancer) in combination with chemical insecticides or the bacterial insecticide Bacillus thuringiensis against $S$. littoralis, S. exigua (in cotton and soybean fields), $P$. gossypiella and E. insulana (in cotton fields) through laboratory and field experiments. In addition, the adversely influence of these combinations on the natural enemies associated with the target pests were estimated under field conditions.

\section{MATERIAL AND MEHTODS}

Bioenhancer: An insect feeding stimulant and attractant. It contains $35 \%$ active ingredients (disaccharides, hydrolyzed starch, whey and vegetable oil) and 65\% inert ingredients. Its rate of application was $5 \% /$ feddan.

Chemical insecticides:

Selecron: Selecron 6 EC, 8 EC. Formulation: (Organic phosphate insecticide), O-(4- bromo-2- chlorophenyl) O- ethyl S- propyl phosphoro-thioate. It was applied at a rate of $750 \mathrm{~cm}^{3} /$ feddan.

Reldan: (Chlorpyrifos-methyl) 2 EC, 25\% WP, 1\% G, 6 1b/gal oil. Formulation: O, O-dimethyl O-(3, 5, 6trichloro-2-pyridimyl) phosphorothioate). It was applied at a rate of $0.005-0.75$, a.i./A. in laboratory the concentrations of $0.025, .05,0.1,0.2,0.4$ and $0.8 \mathrm{ppm}$ was used.

Dursban: $48 \%$ EC. It was applied at a rate of 1liter /feddan. In the laboratory the concentrations were of $0.05,0.1,0.2,0.4$ and $0.8 \mathrm{ppm}$.

Bioinsecticides: Dipel 2X: (Selective bacterial insecticide) B. thuringiensis subsp. kurstaki 32000 International Units/mg. It was applied at a rate of $200 \mathrm{~g}$ / feddan. 
Agerin: B. thuringiensis 32000 International Units/mg. It was applied at a rate of $250 \mathrm{~g} /$ feddan. In the laboratory, the concentrations used were $10 \times 10^{5}, 20 \times 10^{5}, 40 \times 10^{5}, 80 \times 10^{5}$ and $160 \times 10^{5}$ I.U. for S.littoralis and $5 \times 10^{4}, 10 \times 10^{4}, 20 \times 10^{4}, 40 \times 10^{4}$, $80 \times 10^{4}$ and $160 \times 10^{4}$ I.U. for P. gossypiella and $E$. insulana.

\section{Biofly: Beauveria bassiana fungus applied at rate of $100 \mathrm{~cm}^{3} / 100$ liter water.}

Laboratory experiments: S. littoralis, $P$. gossypiella and $E$. insulana were kept under the laboratory conditions of $27 \pm 1^{\circ} \mathrm{C}$ and $65 \pm 5 \%$ R.H.. S. littoralis was reared according to the technique used by Ibrahim (1974), while P. gossypiella and E. insulana were reared according to the technique described by Abdel- Hafez et al. (1982). Castor leaves, cotton bolls were dipped in each compound and left for drying, then offered to the $4^{\text {th }} S$. littoralis, $1^{\text {st }}$ instar $P$. gossypiella and E. insulana larvae.

The following procedures were followed in all experiments:

Three replicates of ten larvae each into a cup $(6 \times 7.5 \mathrm{~cm})$ were fed on caster bean leaves (for $S$. littoralis) and the cotton bloom (for $P$. gossypiella and E. insulana) contaminated with bioenhancer and bioinsecticides for a period of 48 hours. Pests treated for 24 only with the chemical insecticides. Then surviving larvae were put in cups free of treatment till pupation. Mortality was recorded daily. Also, the percentage of pupation and emerged adults were estimated. (2) Before the treatment, larvae were starved for sixth hours in order to obtain rapid simultaneous ingestion of the offered food. (3). The control was conducted using the castor-bean leaves and blooms dipped in water only and left to dry.

Field experiments: Cotton field: Experiments were carried out at Sakha Research Station, (Kafr ElSheikh governorate) during 2003 season. Cotton variety "Giza 88 was planted ont 24 March 2003. An area of about a feddan was chosen and divided into 24 equal plots in randomized complete blocks. Each plot was about $42 \mathrm{~m}^{2}=6 \mathrm{mx} 7 \mathrm{~m}$ in size. The plots were specified for 8 treatments with 3 replicates and the untreated (control). Treatments included the bioenhancer, agerin, biofly, the chemical insecticides (reldan for leafworm \& dursban for bollworms) and their combinations with bioenhancer ( $1 / 2$ bioenhancer+ $1 / 2$ agerin, $1 / 2$ bioenhancer+ $1 / 2$ biofly and $1 / 2$ bioenhancer+ $1 / 2$ each of the chemical insecticide).

Soybean field: Soybean "Giza 111" was planted on June $15^{\text {th }}$ 2003. An area of about half feddan was chosen and divided into 30 equal plots in randomized complete blocks. Each plot was about $42 \mathrm{~m}^{2}=6 \mathrm{mx} 7 \mathrm{~m}$ in size. The plots were specified for 10 treatments with 3 replicates and the untreated (control). Treatments included the bioenhancer, dipel 2x, agerin, biofly, the chemical insecticides (selecron) and their combinations with bioenhancer (( $1 / 2$ bioenhancer+ $1 / 2$ dipel $2 x ; 1 / 2$ bioenhancer+ $1 / 2$ agerin; $1 / 2$ bioenhancer+ $1 / 2$ biofly and $1 / 2$ bioenhancer+ $1 / 2$ selecron).

According to the size of eaten part of leaf (the defoliation is measured as a percentage of the leaf area destroyed by the pests); the cumulative damage caused by the defoliator larvae was estimated by scoring the damage ( 0 to 5 ) of each of 100 randomly chosen leaves. Rate of infestation was calculated according to the formula given by Kasopers (1965). As for the damage caused by the bollworms, 50 cotton bolls were randomly chosen from each treatment and inspected for any symptoms of infestation, and the percentage of infested bolls subsequently calculated. For predators, samples were taken by 5 randomly double sweeping net strokes/plot (10-strokes/ treatment). The collected predators were transferred to the laboratory for identification and counting. In case of parasitoids, 30 of each of the defoliating larvae were collected weekly and transferred to the laboratory, where each larva was kept in a glass vial $(6 \times 10 \mathrm{~cm})$ covered with muslin cloth and provided daily throughout their developmental period with fresh green top shoots of plants. Emerging parasitoids were collected daily, identified and the percentage of parasitism was calculated

Spray applications: Used pesticides were applied by means of 20L. knapsack sprayer using a total volume of $200 \mathrm{~L} /$ feddan. Different treatments were applied in bi-weekly interval in the second treatment.

Statistical analysis: Laboratory data: The $\mathrm{LC}_{50}$ was determined by using Finney (1952) and corrected according to Abbott's formula (1925).

Field Data: Data were statistically analyzed by ANOVA and mean values were separated by the least significant difference (L.S.D.) procedure (Snedecor and Cochran, 1980) at $\mathrm{P}=5 \%$. Percent reduction in each treatment was calculated using Henderson's formula (Henderson \& Tilton, 1955).

\section{RESULTS AND DISCUSSION}

Laboratory experiments: Data presented in table (1) show that the $\mathrm{LC}_{50}$ values of $4^{\text {th }}$ instar $S$. littoralis larvae were $0.00,69.57 \times 10^{5}$ I.U., $0.060 \mathrm{ppm}$ for bioenhancer, agerin (after 72 hours of treatment) and 
reldan (after 24 hours of treatment) alone. Respective values were $38.46 \times 10^{5}$ I.U. and $0.052 \mathrm{ppm}$ for the combinations of different agerin and reldan concentrations with $5 \%$ of bioenhancer. For newly hatched of $P$. gossypiella and E. insulana larvae, the $\mathrm{LC}_{50}$ values were $0.00 \& 0.00,10.43 \times 10^{4}$ I.U. \& 8.36 x10 ${ }^{4}$ I.U., $0.079 \& 0.096$ ppm $6.47 \times 10^{4}$ I.U. \& 4.92 $\mathrm{x} 10^{4}$ I.U. and $0.056 \& 0.071 \mathrm{ppm}$ for bioenhancer, agerin, dursban, agerin + bioenhancer and dursban + bioenhancer, respectively. The results indicated that the feed stimulant was exhibited highest degree of efficiency against target lepidopterous larvae when combined with both chemical insecticide and bioinsecticides. But when it was used alone, it had no obvious effects. In agreement to our findings Naguib et al. (1994) indicated that E. insulana larvae were more susceptible to bio-compounds than $P$. gossypiella larvae. While $P$. gossypiella larvae were more susceptible to esfenvalerate as insecticide than E. insulana. Chandler (1993) observed that the insect feeding stimulant (Konsume 5\%) mixed with diflubenzuron increased the fall armyworm, Spodoptera frugiperda (Smith) larval mortality significantly as compared with diflubenzuron alone.

Table 1: Laboratory bioassay and comparative toxicity of bioenhancer alone, bioinsecticides (after

72 hours of treatments) and chemical insecticides concentrations in combinations with bioenhancer (after 24 hours of treatments) against S. littoralis, P. gossypiella, E. insulana

\begin{tabular}{|c|c|c|c|}
\hline \multirow[t]{2}{*}{ Treatments } & \multirow{2}{*}{$\mathrm{LC}_{50}$} & \multirow{2}{*}{ Slope } & \multirow{2}{*}{$\begin{array}{r}\begin{array}{r}\text { Confidence } \\
\text { limits (P 0.05) }\end{array} \\
\mathrm{LC}_{50}\end{array}$} \\
\hline & & & \\
\hline & & & S. littoralis \\
\hline Bioenhancer & 0.00 & 0.00 & 0.00 \\
\hline Agerin & $69.57 \times 10^{5}$ & 1.26 & $55.09: 91.23$ \\
\hline Reldan & 0.060 & 1.66 & $0.049: 0.072$ \\
\hline Agerin+ Bioenhancer & $38.46 \times 10^{5}$ & 1.38 & $31.45: 46.91$ \\
\hline \multirow[t]{2}{*}{ Reldan+ Bioenhancer } & 0.052 & 1.74 & $0.042: 0.064$ \\
\hline & & & P. gossypiella \\
\hline Agerin & $10.43 \times 10^{4}$ & 1.20 & $7.69: 13.30$ \\
\hline Dursban & 0.079 & 1.77 & $0.061: 0.095$ \\
\hline Agerin+ Bioenhancer & $6.47 \times 10^{4}$ & 1.15 & $4.01: 8.68$ \\
\hline Dursban+ Bioenhancer & 0.056 & 1.74 & $\begin{array}{r}0.039: 0.070 \\
\text { E. insulana }\end{array}$ \\
\hline Agerin & $8.36 \times 10^{4}$ & 1.20 & $5.81: 10.78$ \\
\hline Dursban & 0.096 & 1.59 & $0.076: 0.12$ \\
\hline Agerin + Bioenhancer & $4.92 \times 10^{4}$ & 1.61 & $3.01: 6.38$ \\
\hline Dursban + Bioenhancer & 0.071 & 1.63 & $0.052: 0.088$ \\
\hline
\end{tabular}

Field experiments: Pests treatments: $1^{\text {st }}$ In cotton field (Cotton defoliating and bollworms): Data in table, 2 and Fig. 1 show that the reduction in the defoliating damage was estimated as $12.87,22.40,17.49$, 34.98, $42.16,30.42$ and $26.35 \%$ for bioenhancer, agerin, biofly, reldan, $1 / 2$ bioenhancer $+1 / 2$ reldan, $1 / 2$ bioenhancer $+1 / 2$ agerin and $1 / 2$ bioenhancer $+1 / 2$ biofly, respectively. The damage of bollworms was reduced to $18.54,38.76,29.22,61.81,69.09,56.76$ and
$50.86 \%$ at different treatments, respectively. Cotton leaves damaged by the cotton leafworm were significantly higher in the control as compared to treatments. In case of bollworms, reldan and other combined treatments were significantly different from the untreated control. Neither bioenhancer treatment as significantly different from either agerin and biofly treatments or the untreated control.

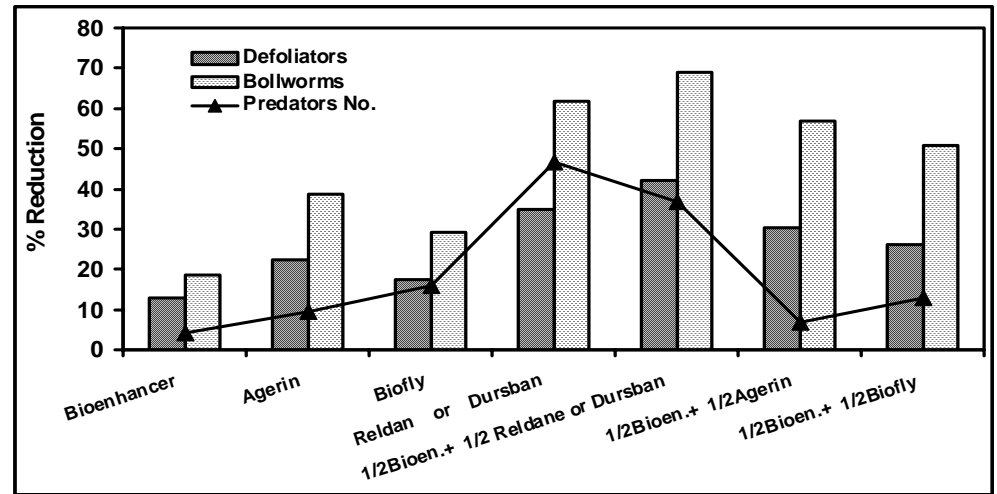

Fig 1. Percent reduction in defoliators and bollworms pest damage and associated predatory species at different treatments, in cotton fields, 2003 
Table 2: Effect of bioenhencer and its combinations in reducing the damage rate caused by cotton leafworm and bollworms in Kafr ElSheikh cotton fields, 2003

\begin{tabular}{|c|c|c|c|c|c|c|c|c|}
\hline \multirow{3}{*}{ Months } & \multicolumn{8}{|c|}{$\%$ of average damage in different treatments } \\
\hline & Control & $\begin{array}{l}\text { Bioen- } \\
\text { hancer }\end{array}$ & Agerin & Biofly & $\begin{array}{l}\text { Reldan or } \\
\text { Dursban }\end{array}$ & $\begin{array}{ll}1 / 2 & \text { Bioen.+ } \\
1 / 2 & \text { Reldane } \\
\text { or } & \text { Dursban }\end{array}$ & $\begin{array}{l}\text { 1/2Bioen.+ } \\
1 / 2 \text { Agerin }\end{array}$ & $\begin{array}{l}1 / 2 \\
\text { Bioen.+ } \\
1 / 2 \text { Biofly }\end{array}$ \\
\hline & \multicolumn{8}{|c|}{ *Cotton Leafworm } \\
\hline July & 25.36 & 24.86 & 22.00 & 23.50 & 19.00 & 17.17 & 20.80 & 21.60 \\
\hline Aug. & 34.74 & 29.47 & 26.03 & 27.93 & 22.63 & 19.76 & 23.56 & 24.81 \\
\hline Sept. & 43.86 & 36.23 & 32.64 & 34.34 & 25.95 & 23.18 & 27.96 & 30.16 \\
\hline Overall & 34.65 & 30.19 & 26.89 & 28.59 & 22.53 & 20.04 & 24.11 & 25.52 \\
\hline \% Reduction & & -12.87 & -22.40 & -17.49 & -34.98 & -42.16 & -30.42 & -26.35 \\
\hline \multirow{2}{*}{$\begin{array}{l}\text { L.S.D. } \quad 5 \% \\
\text { (weekly) }\end{array}$} & \multirow{2}{*}{\multicolumn{8}{|c|}{$\begin{array}{l}4.3019 \\
* * \text { Bollworms }\end{array}$}} \\
\hline & & & & & & & & \\
\hline July & 9.00 & 6.50 & 4.50 & 6.00 & 3.50 & 3.00 & 3.00 & 4.50 \\
\hline Aug. & 30.00 & 24.00 & 18.00 & 20.50 & 9.50 & 7.50 & 11.50 & 13.25 \\
\hline Sept. & 50.00 & 42.00 & 32.00 & 36.50 & 21.00 & 17.00 & 24.00 & 26.00 \\
\hline \multirow{2}{*}{$\begin{array}{l}\text { Overall } \\
\text { \% Reduction }\end{array}$} & 29.67 & 24.17 & 18.17 & 21.00 & 11.33 & 9.17 & 12.83 & 14.58 \\
\hline & & -18.54 & -38.76 & -29.22 & -61.81 & -69.09 & -56.76 & -50.86 \\
\hline $\begin{array}{l}\text { L.S.D. } \quad 5 \% \\
\text { (weekly) }\end{array}$ & 11.6428 & & & & & & & \\
\hline
\end{tabular}

*Pre-treatment $\left(\right.$ Control) $=17.051$ st spray $\left(\right.$ June $\left.28^{\text {th }}\right) \quad \&$ 2nd spray $\left(\right.$ July $\left.19^{\text {th }}\right) ; * *$ Pre-treatment=3.00 Sprayed at July $26^{\text {th }}$

$2^{\text {nd }}$ In soybean field (Defoliators): Soybean leaves damaged by the various defoliator larvae (e.g. $S$. littoralis and S. exigua) were reduced to 9.40, 25.54, 30.41, 23.42, 48.21, 54.20, 34.21\%, 38.41 and $29.53 \%$ for bioenhancer, dipel 2x, agerin, biofly, selecron, $1 / 2$ bioenhancer $+1 / 2$ selecron, $1 / 2$ bioenhancer $+1 / 2$ dipel $2 x, 1 / 2$ bioenhancer $+1 / 2$ agerin and $1 / 2$ bioenhancer $+1 / 2$ biofly, respectively (Table 3 and Fig.2). Defoliator larvae damages were significantly higher as the control compared with the treatments of dipel 2x, agerin, biofly and selecron alone or in combinations. Neither bioenhancer treatment as significantly different from dipel $2 x$, agerin and biofly (alone or combined with bioenhencer) treatments or the untreated control. These results agree with those of Pfrimmer (1983) who stated that the addition of feeding stimulants to a synthetic pyrethroid applied, to control the lepidopterous larvae in cotton field, at half the normal rate resulted in control equal to applications at the full rate. Abdally et al. (1987) decided that coax did not significantly increase mortality of Heliothis spp. when added, at $2 \mathrm{~kg} / \mathrm{ha}$, to the microbial insecticides but caused as much mortality as they did when applied alone. Chandler (1994) found that the addition of the feeding stimulant (Konsume) to the insect growth regulator (RH-5992) resulted in higher levels of $S$. frugiperda larval mortality in corn field. Plants treated with Konsume resulted in a significant reduction in damage by $S$. frugiperda compared with the untreated control. However, plants treated with Konsume alone did not provide needed levels of economic fall armyworm control (as the findings are observed with the spray table test). Moreover, feeding raspberry leaves treated with $B$. thuringiensis + feeding stimulants (e.g. Pheast) to larval Choristoneura rosaceana, resulted in a 93\% greater mortality than that observed in larvae feeding on $\mathrm{Bt}$ alone ( $\mathrm{Li}$ and Fitzpatrick, 1997).

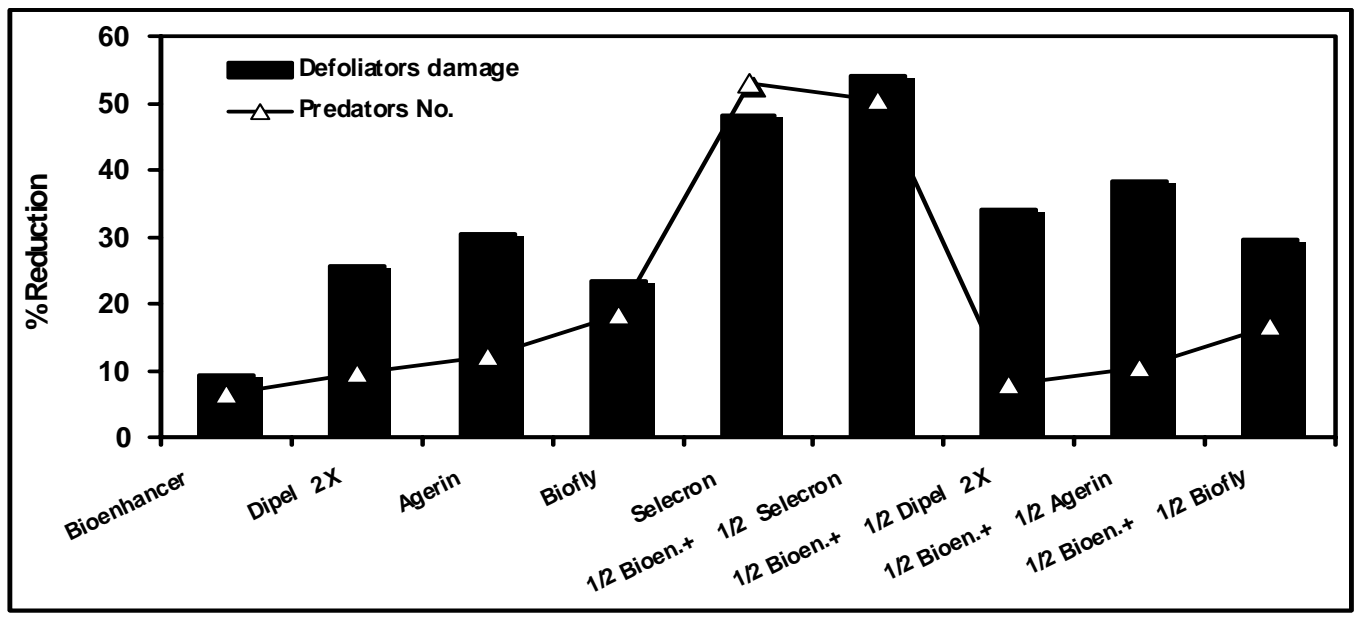

Fig 2. Percent reduction in defoliator pest damage and associated predatory species at different treatments, in soybean fields, 2003 
Table 3. .Effect of bioenhencer and its combinations in reducing the damage rate caused by defoliator pests in Kafr El-Sheikh soybean fields, 2003.

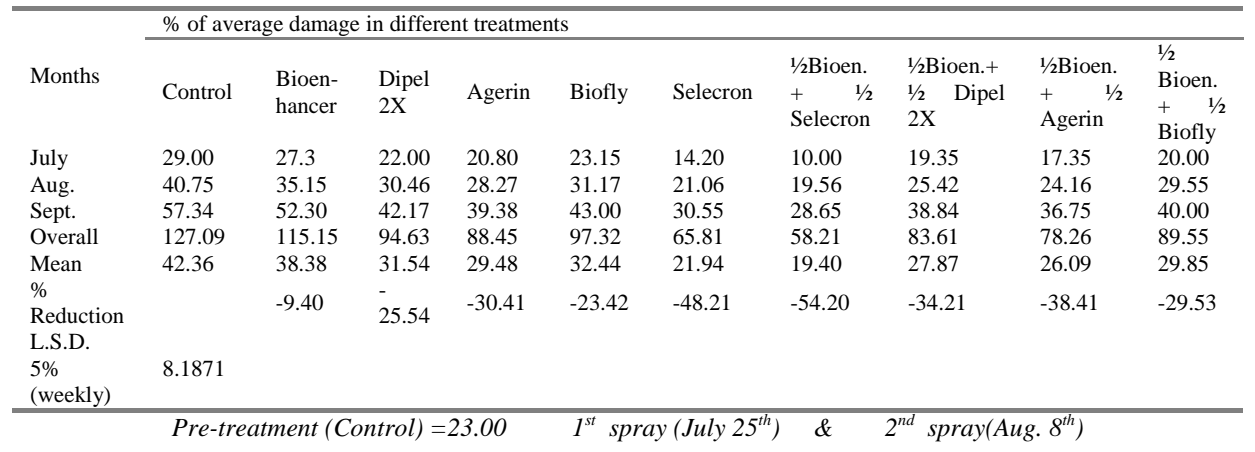

Effect on Natural enemies: $9^{\text {th }}$ Predators: A. In cotton field: Predaceous species collected during the period of the experiment were: six coleopterous, Cocinella undecimpunctata L., Cydonia vicina var. nilotica Muls and Scymnus spp. (interruptus Goeze, syriacus Mars. and globossus var. pieceus Ws.) (Cocinellidae) and Paederus alfierii Koch (Staphylinidae); two hemipterous Orius spp. (albidipennis Reut. and laevigatus Fieb.) (Anthocoridae); one neuropteran Chrysoperla carnea Steph. (Chrysopidae). The mean number of predators collected, during the period of experiment, from bioenhancer, agerin, biofly, reldan, $1 / 2$ bioenhancer $+1 / 2$ reldan, $1 / 2$ bioenhancer $+1 / 2$ agerin and
$1 / 2$ bioenhancer $+1 / 2$ biofly treated plots, were 12.98 , 12.25, 11.39, 7.22, 8.56, 12.59 and 11.78 individuals (Table, 4\& Fig.1). Correspondent number in the control was 13.53 predators. These results indicated that bioenhancer and the bioinsecticide had the least harmful effect on the entomophagous insect populations. Bioenhancer, agerin and biofly treatments were insignificantly different from either their combined treatments or the untreated control. While significant differences between control or bioenhancer treatment and the chemical insecticides alone or in combination with bioenhancer were found.

Table (4): Effect of bioenhencer and its combinations on the average numbers of predator adult species collected after the different treatments in cotton fields, season 2003.

\begin{tabular}{|c|c|c|c|c|c|c|c|c|}
\hline \multirow[b]{2}{*}{ Months } & \multicolumn{8}{|c|}{$\%$ of average damage in different treatments } \\
\hline & Control & $\begin{array}{l}\text { Bioen- } \\
\text { hancer }\end{array}$ & Agerin & Biofly & $\begin{array}{l}\text { Reldan } \\
\text { or } \\
\text { Dursban }\end{array}$ & $\begin{array}{l}1 / 2 \text { Bioen.+ } \\
1 / 2 \\
\text { Reldane } \\
\text { or } \\
\text { Dursban }\end{array}$ & $\begin{array}{l}\text { 1/2Bioen.+ } \\
1 / 2 \text { Agerin }\end{array}$ & $\begin{array}{l}1 / 2 \text { Bioen. }+ \\
1 / 2 \text { Biofly }\end{array}$ \\
\hline July & 19.50 & 18.75 & 17.84 & 16.67 & 11.00 & 12.17 & 18.17 & 17.00 \\
\hline Aug. & 11.25 & 10.84 & 10.25 & 9.34 & 5.50 & 6.83 & 10.42 & 10.00 \\
\hline Sept. & 9.84 & 9.34 & 8.67 & 8.17 & 5.17 & 6.67 & 9.17 & 8.33 \\
\hline Overall & 13.53 & 12.98 & 12.25 & 11.39 & 7.22 & 8.56 & 12.59 & 11.78 \\
\hline$\%$ & & -4.07 & -9.46 & -15.82 & -46.64 & -36.73 & -6.95 & -12.93 \\
\hline $\begin{array}{l}\text { Reduction } \\
\text { L.S.D. 5\% } \\
\text { (weekly) }\end{array}$ & 3.9602 & & & & & & & \\
\hline
\end{tabular}

In soybean field: The predaceous species collected during the period of the experiment were: six coleopterous, C. undecimpunctata, C. vicina var. nilotica, C. vicina var. subsignata Pic. and Scymnus spp. (interruptus and syriacus) (Cocinellidae) and $P$. alfierii (Staphylinidae); two hemipterous Orius spp. (albidipennis and laevigatus) (Anthocoridae); one neuropteran C. carnea (Chrysopidae). The overall of the average numbers of predators collected in the three months of plantation from the control, bioenhancer, dipel 2x, agerin, biofly, selecron, $1 / 2$ bioenhancer $+1 / 2$ selecron, $1 / 2$ bioenhancer $+1 / 2$ dipel $2 x$,
$1 / 2$ bioenhancer $+1 / 2$ agerin and $1 / 2$ bioenhancer $+1 / 2$ biofly plots, reached 35.03, 33.28, 32.30, 31.23, 28.73, $16.80,17.75,32.70,31.78$ and 29.84 individuals, respectively, (Table,5 \& Fig.,2). As shown in the table and figure the predators attracted to bioenhancer treated plots, which was less harmful to them. Bioenhancer, agerin and biofly treatments were insignificantly different from either their combined treatments or the untreated control. While significant differences between control or bioenhancer treatment and the chemical insecticides alone or in combination with bioenhancer were found. 
Table (5) Average numbers of predators counted at different treatments in soybean fields, season 2003.

\begin{tabular}{|c|c|c|c|c|c|c|c|c|c|c|}
\hline \multirow[b]{2}{*}{ Months } & \multicolumn{10}{|c|}{$\%$ of average damage in different treatments } \\
\hline & $\begin{array}{l}\text { Contro } \\
1\end{array}$ & $\begin{array}{l}\text { Bioen- } \\
\text { hancer }\end{array}$ & $\begin{array}{l}\text { Dipel } \\
2 \mathrm{X}\end{array}$ & Agerin & Biofly & Selecron & $\begin{array}{l}1 / 2 \text { Bioen.+ } \\
1 / 2 \\
\text { Selecron }\end{array}$ & $\begin{array}{lc}\text { 1/2Bioen. }+ \\
1 / 2 & \text { Dipel } \\
2 \mathrm{X} & \end{array}$ & $\begin{array}{l}\text { 1/2Bioen.+ } \\
\text { 1/2 Agerin }\end{array}$ & $\begin{array}{l}1 / 2 \\
\text { Bioen.+ } \\
1 / 2 \text { Biofly }\end{array}$ \\
\hline July & 10.75 & 10.00 & 9.75 & 9.00 & 8.75 & 4.25 & 5.50 & 10.00 & 9.50 & 9.00 \\
\hline Aug. & 10.00 & 9.33 & 9.05 & 8.60 & 8.10 & 4.63 & 5.00 & 9.20 & 8.90 & 8.21 \\
\hline Sept. & 13.03 & 12.20 & 11.75 & 11.88 & 10.88 & 6.75 & 6.25 & 12.00 & 11.88 & 11.25 \\
\hline Overall & 35.03 & 33.28 & 32.30 & 31.23 & 28.73 & 16.80 & 17.75 & 32.70 & 31.78 & 29.84 \\
\hline Mean & 11.68 & 11.09 & 10.77 & 10.41 & 9.58 & 5.63 & 5.92 & 10.90 & 10.59 & 9.95 \\
\hline $\begin{array}{l}\% \\
\text { Reduction } \\
\text { L.S.D. }\end{array}$ & & -6.61 & -9.56 & -12.15 & -18.20 & -52.86 & -50.46 & -7.83 & -10.43 & -16.71 \\
\hline $\begin{array}{l}5 \% \\
\text { (weekly) }\end{array}$ & 1.7787 & & & & & & & & & \\
\hline
\end{tabular}

Parasitoids: In cotton field: The solitary larval hymenopteran endoparasitoid Microplitis rufiventris Kok. was recorded from $26^{\text {th }}$ July till $31^{\text {st }}$ August 2003 on S. littoralis larvae. The percentage of parasitism in the untreated plots was 20, 2023.33 and $6.67 \%$ on July $26^{\text {th }}$, Aug. $3^{\text {rd }}$, Aug. $10^{\text {th }}$ and Aug. $17^{\text {th }}$, respectively. These percentage increased during the same period in the plots treated with the feeding stimulant (Bioenhencer (5\%)) to be 33.33\% + 5 direct collecting cocoons, $40 \%+3$ cocoons, $23.33 \%+4$ cocoons, 1 open cocoon and 3 cocoons on July $26^{\text {th }}$, Aug. $3^{\text {rd }}$, Aug. $10^{\text {th }}$, Aug. $17^{\text {th }}$ and Aug. $31^{\text {st }}$ respectively. Also, 3 and 4 cocoons of the same parasitoid was appeared in the plots treated with agerin and bioenhancer on Aug. $3^{\text {rd }}$ and Aug. $10^{\text {th }}$. The safety of chemical and bioinsecticide with or without feeding stimulant on different predatory and parasitoid species was previously reported by Patel and Yadav (1995) who found that the chemical insecticide (monocrotophos) was effective for reducing the pest population of Amrasca biguttula biguttula, in cotton fields in Anand, Gujarat, India and it had an adverse effect on the chrysopid predator Chrysopa scelestes. Attique and Ghaffar (1996) observed that in Pakistan cotton fields the predator populations in the treated plots with insecticides like Promet (furathiocarb) and Confidor (imidacloprid) were lower than in the untreated control. Also, Tillman (1996) studied the susceptibility of certain insecticides for both males and females of the parasitoids, Cardiochiles nigriceps, Cotesia marginiventris, and Microplitis croceipes, of Heliothis virescens, where thiodicarb and oxamyl were appeared less toxicity than acephate. Esfenvalerate was the least toxic pyrethroid to females of C. marginiventris. Studebaker et al. (1999) stated $18.8 \% 62.5$ and $62.8 \%$ mortality in Orius insidiosus by the treated cotton leaves with the selected insecticides spinosad, imidacloprid and indoxacarb, respectively. Fipronil and cyhalothrin caused $100 \%$ mortality. O. insidiosus adults ceased and never resumed feeding, after exposure to imidacloprid-treated leaves.

In conclusion, the use of the chemical and bio insecticides resulted in significant levels of the defoliators and the boll worms larval control on both cotton and soybean fields as compared with the untreated plots. Addition of insect feeding stimulant to the chemical and bio insecticides provided significant effect to the defoliators and the bollworms mortality as compared to the use of the chemical and bio insecticides alone. Field results confirmed our laboratory findings, which indicated that the use of insect feeding stimulant enhanced the activity of the different insecticides and increase the larval mortality. So, feeding stimulants often reduce insecticide use and increase the efficacy of the insecticide or entomopathogen combined. Moreover, feeding stimulants attracted more the natural enemies and reduced the effects of pesticides on non-target insects, where the parasitoids and predators have been minimal.

Acknowledgments: The authors wish to thank Prof. Dr. El-Heneidy (Biological control Dept., Plant Prot. Res. Inst.) for his advise and reviewed the manuscript. Dr. El-Torkey, A. (Dept. of Taxonomy) is thanked for his help in identifying the different parasitoids and predators in these studies

\section{REFERENCES}

Abdally-A; K. M. Makkouk and C. Cardona (1987): Control of Heliothis spp. on chickpea by insect pathogenic nuclear polyhedrosis virus. Arab Journal of Plant Protection. 5 (2:) 78-80. 
Abbott, W.S. (1925): A method of computing the effectiveness of an insecticide. J. Econ. Entomol. 18: 265-267.

Abdel-Hafez, A.; A.G. Metwally and M.R.A. Saleh (1982): Rearing pink bollworm, Pectinophora gossypiella (Saunders) on kidney bean diet in Egypt (Lepidoptera: Gelechiidae). Res. Bull., Fac. Agric., Zagazig Univ., No. 576, 10pp.

Amin, A.A.A., M. Gergis, and M. El-Naggar (2001): Alternative infield refuge strategies for controlling certain cotton key pests in middle Egypt. The ESA 2001 Annual Meeting - December 2001: An Entomological Odyssey of ESA, San Diego, CA

Attique, M.R. and A. Ghaffar (1996): Control of early season sucking pests of cotton with seed protectant insecticides and their impact on natural enemies and yield of seed cotton. Pakistan Journal of Zoology. 28 (3): 253.

Chandler, L. D. (1993): Use of feeding stimulants to enhance insect growth regulator induced mortality of the fall armyworm (Lepidoptera, Noctuidae) larvae. Florida Entomol. 76: 316-326.

Chandler, L. D. (1994): Evaluation of insect growth regulator-feeding stimulant combinations for management of fall armyworm (lepidoptera: noctuidae). Florida Entomol. 77 (4): 411-424.

El-Kifl, A.H.; A.T.A. Wahab; M.A. Assem and A.A. Metwally (1974): List of insects, mites and pests associated with leguminous crops in Egypt. Bull. Soc. Ent. Egypt 58: 297-302.

Finney, DJ. (1952): Probit Analysis, Cambridge University Press, Cambridge. 333pp.

Ibrahim, A.A. (1974): Studies on the biological control of Spodoptera littoralis (Boisd.) in A.R.E.. Ph.D. Thesis, Faculty of Agriculture, Cairo University. 282 pp.

Hamed, M.A.A. (1977): Survey of insects on soybean. MSc. Thesis Fac. Agric. El-Azhar Univ. Egypt.

Henderson, C.S. and Tilton, E.W. (1955): Tests with accaricide against the brown wheat mite. J. Econ. Entomol. 48: 157-161.

Hough-Goldstein, J.; A.M. Tisler; G.W. Zehnder and K.A. Uyeda (1991): Colorado potato beetle (Coleoptera : Chrysomelidae) consumption of foliage treated with Bacillus thuringiensis var. san diego and various feeding stimulants. J. Econ. Entomol.. 84: 87-93.
Kasopers, H. (1965): Erorterungen zür prüfung von Fungiziden in obsthau. Pflanzensc-hutz-Nachrichten. "Bayer" 18: 83-92.

Li, S.Y. and S. M. Fitzpatrick (1997): Responses of larval Choristoneura rosaceana (Harris) (Lepidoptera: Tortricidae) to a feeding stimulant. Can. Entomol. 129: 363369.

Naguib, SM; AM Rashad, M.E. Wahba; H.M. El-Gemmeiy (1994): Responses of Pectinophora gossypiella (Saunders) and Earias insulana (Boisd.) to control bio- and chemical control. Bull. ent. Soc. Egypt. Econ. Ser. 25-32.

Pfrimmer, TR (1983): Heliothis spp.: insecticidal control evaluations on cotton at Stoneville, MS. Journal of the Georgia Entomological Society. 18 (4): 464-479.

Patel, I.S. and D.N. Yadav (1995): Susceptibility of Amrasca biguttula biguttula and Chrysopa scelestes in cotton (Gossypium species) to three systemic insecticides. Indian Journal of Agricultural Sciences. 65 (4): 308-309.

Potter, M.F. and T.F. Watson (1983): Garbanzo bean as a potential feeding stimulant for use with a nuclear polyhedrosis virus of tobacco budworm (Lepidoptera: Noctuidae). J. Econ. Entomol.. 76 : 449-451.

Sharma, H.C.; K.K. Sharma; N. Seetharama and R. Ortiz (2000): Prospects for using transgenic resistance to insects in crop improvement. Electronic Journal of Biotechnology. $1-25$

Snedecor, G.W. and W.G. Cochran (1980): Statistical methods, $2^{\text {nd }}$ ed. The Iowa State University Press, Ames, Iowa. 318pp.

Studebaker, G.E.; T. J. Kring; P. Dugger and D. Richter (1999): Lethal and sub-lethal effects of selected insecticides on Orius insidiosus. Proceedings Beltwide Cotton Conferences, Orlando, Florida, USA, 3-7 January, 1999, 2: 1203-1204

Tantawy, A.M.; F. Haydar and A.H. Shaheen (1989): The effect of intercropping with soybean and cowpea in maize on the major insect pests attacking each crop. Proc. $1^{\text {st }}$ Conf. Econ. Ent., Cairo, 11-14 Dec. 1989, Vol. I: 219-228.

Tillman-PG (1996): Susceptibility of three parasitoids of Heliothis virescens to field rates of selected cotton insecticides. Proceedings Beltwide Cotton Conferences, Nashville, TN, USA, January 9-12, 1996, 2: 793-795. 